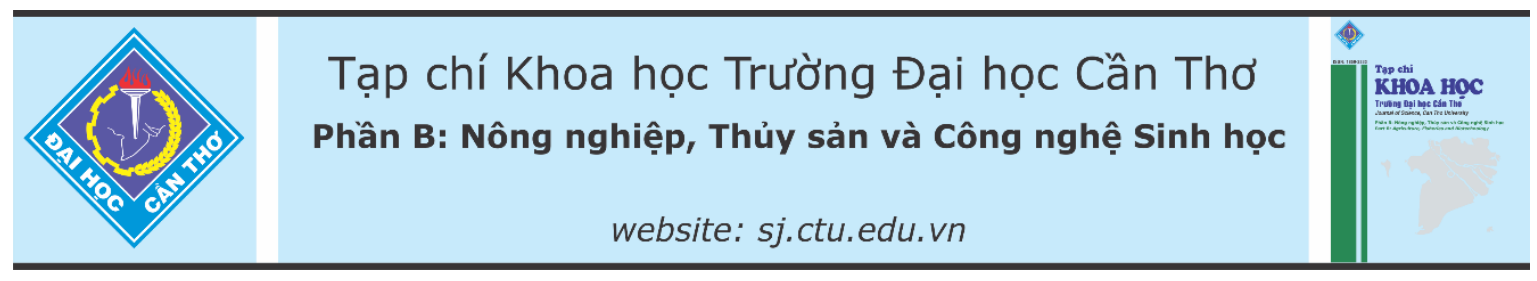

DOI:10.22144/ctu.jvn.2021.093

\title{
NGHIÊN CÚU SỬ CHUYỂN HOÁ SINH LÝ, HÓA SINH THEO TUỔI PHÁT TRIỂ CỦA QUẢ CÀ CHUA (Solanum lycopersicum L.) TRỒNG TẠI THANH HÓA
}

\author{
Lê Văn Trọng* và Hà Thị Phương \\ Khoa Khoa hoc Tư nhiên, Truờng Đại học Hồng Đức \\ *Nguoòi chịu trách nhiệm về bài viết: Lê Văn Trọng (email: levantrong@hdu.edu.vn)
}

\section{Thông tin chung:}

Ngày nhận bài: $12 / 01 / 2021$

Ngày nhận bài sủa: 17/04/2021

Ngày duyệt đăng: 25/06/2021

Title:

Study of some biochemical and physiological metabolism of tomato fruit (Solanum lycopersicum L.) over fruit development stages: a case study in Thanh Hoa province

\section{Tù khóa:}

Chi tiêu sinh lý, chi tiêu sinh hóa, chín sinh lý, quả cà chua

\section{Keywords:}

Biochemical indexes, physiological indexes, physiological maturity, tomatoes

\begin{abstract}
Research on the physiological and biochemical metabolism according to the developmental age of tomatoes, NHP11 variety planted in 2019, in Thanh Hoa province from formation to maturity to determine the time of maturity of the fruit is the basis for the harvest and preservation of fruit. Results showed that tomatoes fruit reached the maximum size when being 46 days old. The content of chlorophyll a and $b$ increased gradually from fruit formation to 26 days old, then decreased rapidly until the fruit was fully ripe, carotenoid increased gradually until the fruit ripens. Starch content and total organic acid content increased gradually and peaked at 26 days old, then gradually decreased. Reducing sugars and vitamin $C$ content increased during the early stages and peaked at 46 days, then decreased gradually. The activity of $\alpha$ - amylase fluctuated following the fluctuation of starch and reducing sugars, catalase activity increased gradually and reached the maximum when the fruit was at 46 days old and then decreased, peroxidase activity increased continuously until the fruit ripens. This result shows that tomato fruit of NHP11 variety should be harvested at physiological maturity (46 days old) to ensure the high nutritional value and quality of the fruit during storage.
\end{abstract}

\section{TÓM TẮT}

Nghiên cưu sụ chuyển hóa sinh lý, hóa sinh theo tuổi phát triển của quả cà chua, giống NHP11 trồng trong vu Xuân 2019 tại tỉnh Thanh Hóa tù khi hình thành cho đến khi quả chín nhằm xác định thời điểm chín sinh lý là co sở cho việc thu hái và bảo quản quả được tốt hơn. Kết quả cho thấy quả cà chua đạt kích thuơóc gần nhu tối đa khi được 46 ngày tuổi. Hàm lượng diệp luc a và b tăng dần tù̀ khi quả mới hình thành đến 26 ngày tuổi, sau đó giảm nhanh đển khi quả chín, hàm luợng carotenoid tăng dần đến khi quả chín. Hàm luợng tinh bột và acid hũu co tổng số tăng dần và đạt cực đại khi quả 26 ngày tuổi, sau đó giảm dần. Hàm lượng đường khư và vitamin $C$ tăng lên trong suốt nhũng giai đoạn đầu và đạt giá trị cao nhất ở 46 ngày tuổi, sau đó giảm xuống. Hoạt độ của $\alpha$-amylase biến động phù hợp với sụ biến động của tinh bột và đường khư, hoạt độ cactalase tăng dần và đạt cưc đại khi quả được 46 ngày, hoạt độ peroxydase tăng liên tục cho đến khi quả chín. Kết quả này cho thấy quả cà chua nên được thu hoạch ở độ chín sinh lý (46 ngày tuổi) để đảm bảo giá trị dinh dữ̛ng và chất lượng của quả trong quá trình bảo quản. 


\section{1. ĐẶT VẤN ĐỀ}

Cà chua thuộc họ Cà (Solanaceae) có nguồn gốc từ Nam Mỹ, đây là loại cây được trồng khá phổ biến ở các vùng khí hậu nhiệt đới và á nhiệt đới (Poonam et al., 2004). Trên thế giới Trung Quốc là nước sản xuất cà chua lớn nhất, chiếm khoảng một phần tư sản lượng toàn cầu, tiếp theo là Ấn Độ và Hoa Kỳ, các khu vực chế biến tại California chiếm $90 \%$ lượng sản xuất ở Mỹ và $35 \%$ lượng sản xuất thế giới (Hartz et al., 2008). Cà chua là loại cây tiềm năng, dễ canh tác, vì vậy cây cà chua đã trở thành cây trồng quan trọng góp phần phát triển kinh tế và nâng cao đời sống của các hộ nông dân (Erba et al., 2013). Ở nước ta cây cà chua rất được chú trọng phát triển, hàng năm diện tích trồng cà chua đều tăng lên, tuy nhiên năng suất vẫn còn thấp và không ổn định, so với năng suất trung bình toàn thế giới thì năng suất cà chua ở Việt Nam còn quá thấp (Dương Bá Toàn, 2017). Quả cà chua giàu dinh dưỡng, chứa nhiều đường, vitamin $\mathrm{A}$, vitamin $\mathrm{C}$, các khoáng chất quan trọng như calcium, iron, potassium, magnesium... Cà chua là loại quả rất được ưa thích, không chỉ ăn ngon mà còn dễ chế biến, có thể dùng ở dạng rau trộn (salad), chế biến các món ăn, làm quả tươi ở món tráng miệng, nước giải khát...(Tạ Thu Cúc, 2009).

Với nhiều lợi ích, quả cà chua được nhiều nhà khoa học ở Việt Nam và trên thế giới tập trung nghiên cứu. Nghiên cứu của Abdul et al. (2009) cho thấy rằng có sự khác biệt giữa hai kỹ thuật ủ chín cà chua đến chất lượng quả của hai giống cà chua Ibadan-Local và Roma. Nghiên cứu của Cao Kỳ Sơn và ctv. (2008) cho thấy, để sản xuất cà chua trong nhà plastic đạt năng suất và hiệu quả kinh tế cao giá thể phối trộn theo tỷ lệ thể tích tốt nhất đối với cà chua là $40 \%$ đá bọt núi lửa và $60 \%$ mụn xơ dừa, trên nền giá thể này năng suất cà chua đạt 89,66 tấn/ha/vụ. Nguyễn Văn Thao và ctv. (2016) cho rằng các mức bón đạm ảnh hưởng rõ nét tới năng suất quả cây cà chua, trong khi đó, các mức bón phân lân và phân kali làm thay đổi khối lượng quả. Nhìn chung các nghiên cứu hiện nay chủ yếu tập trung vào dinh dưỡng của quả cà chua và các biện pháp nâng cao năng suất của cây cà chua mà chưa có nhiều những nghiên cứu về biến đổi sinh lý hóa sinh của quả cà chua trong quá trình sinh trưởng và phát triển.

Tại Thanh Hóa, cây cà chua được trồng tương đối phổ biến với nhiều loại giống mới cho năng suất cao và ổn định. Tuy nhiên, việc thu hái và bảo quản quả cà chua chưa thực sự có cơ sở khoa học làm cho phần lớn quả cà chua ngoài thị trường chưa đảm bảo chất lượng, ảnh hưởng tới sức khỏe của người tiêu dùng. Mặt khác, vấn đề nghiên cứu về biến đổi sinh lý, hóa sinh của quả cà chua ở trong nước còn hạn chế, vì vậy việc phân tích các chỉ tiêu sinh hóa theo sự sinh trưởng và phát triển của quả là cần thiết để tìm ra thời điểm chín sinh lý giúp người tiêu dùng sử dụng quả tốt hơn.

\section{PHƯƠNG PHÁP NGHIÊN CÚU}

\subsection{Vật liệu và địa điểm nghiên cứu}

Thí nghiệm được bố trí tại Trường THPT Đặng Thai Mai, Xã Quảng Bình huyện Quảng Xương, tỉnh Thanh Hóa từ tháng 12 năm 2018 đến tháng 04 năm 2019. Các chỉ tiêu sinh lý, hóa sinh được thực hiện tại Phòng Thí nghệm Bộ môn Sinh học, Khoa Khoa học Tự nhiên, trường Đại học Hồng Đức.

Giống cà chua NHP11 là sản phẩm của Công ty TNHH Nông Hưng Phú, có tỉ lệ nảy mầm trên $85 \%$, thời gian sinh trưởng đến thu hoạch từ 60-65 ngày sau khi trồng. Quả tròn hơi dẹp, khi chín màu đỏ tươi, thịt dày, kháng bệnh héo rũ tốt.

\subsection{Phương pháp thu mẫu}

Quả cà chua được thu theo phương pháp lấy mẫu hỗn hợp trên toàn diện tích vườn thí nghiệm theo sơ đồ đường chéo tại năm điểm: điểm giữa tâm và bốn điểm chính giữa của các đoạn thẳng nối tâm đến bốn góc của đỉnh. Các cây lấy mẫu này đều phát triển bình thường, không sâu bệnh, có tuổi và điều kiện chăm sóc khá đồng đều. Thí nghiệm tiến hành ở các thời điểm quả được 7, 14, 20, 26, 32, 37, 42, 46, 50 ngày. Khi quả mới hình thành, tiến hành đánh dấu hàng loạt quả trên các cây thí nghiệm, ghi chép theo ngày tháng, ở mỗi thời điểm tiến hành thu mẫu ở 20 cây, mỗi cây 5 quả. Quả cà chua được thu vào buổi sáng, sau đó trộn đều, cho vào túi nylon và ghi phiếu để tiến hành thí nghiệm.

\subsection{Phương pháp phân tích các chỉ tiêu sinh lý}

- Hàm lượng sắc tố trong vỏ quả được xác định bằng phương pháp quang phổ theo công thức của Mac - Kinney (Nguyễn Văn Mã và ctv., 2013).

- Hàm lượng đường khử, tinh bột được xác định theo phương pháp Bertrand (Phạm Thị Trân Châu và ctv., 1996).

- Hàm lượng axit hữu cơ tổng số được xác định theo phương pháp của Ermacov (Ermacov et al., 1972).

- Hàm lượng Vitamin $C$ được xác định theo phương pháp chuẩn độ (Nguyễn Văn Mùi, 2001).

- Hoạt độ $\alpha$ - amylaza được xác định bằng phương pháp quang phổ (Phạm Thị Trân Châu và ctv., 1996). 
- Hoạt độ enzym catalaza được xác định theo phương pháp của Bac và Oparin (Nguyễn Văn Mùi, 2001).

- Hoạt độ enzym peroxydaza được xác định theo phương pháp của Boiarkin (Nguyễ் Văn Mùi, 2001).

\subsection{Phương pháp xử lý số liệu}

Số liệu được xử lý và phân tích phương sai ANOVA bằng phần mềm IRRISTAT 5.0. Các giá trị trung bình được so sánh thông qua giá trị $\mathrm{LSD}_{0,05}$.

\section{KẾT QUẢ VÀ THẢO LUẬN}

\subsection{Sự biến đổi về đường kính và chiều dài của quả cà chua trồng tại Thanh Hóa}

Theo tuổi phát triển, quả cà chua có sự biến đổi về chiều dài và đường kính, theo dõi quá trình thay đổi này cho phép xác định thời điểm quả ngừng sinh trưởng và đạt kích thước tối đa, đây là tiền đề để xác định thời điểm chín của quả. Kết quả cho thấy chiều dài và đường kính quả đều tăng lên trong suốt quá trình sinh trưởng, phát triển (Hình 1,2). Thời điểm quả 7 ngày tuổi chiều dài đạt $2,23 \mathrm{~cm}$ và đường kính quả đạt $2,25 \mathrm{~cm}$. Giai đoạn quả cà chua từ 7 ngày tuổi đến 20 ngày tuổi chiều dài quả biến đổi rõ rệt thể hiện sự khác biệt có ý nghĩa qua phân tích thống kê, giai đoạn này, quả cà chua có tốc độ sinh trưởng nhanh do sự phân chia và dãn dài mạnh mẽ của tế bào (Heller et al., 1995). Sau đó, chiều dài và đường kính quả vẫn tăng lên nhưng với tốc độ chậm hơn và ổn định hơn, đến khi quả được 42 tuần tuổi chiều dài quả đạt $5,66 \mathrm{~cm}$ và đường kính quả đạt $6,11 \mathrm{~cm}$, giai đoạn này tốc độ sinh trưởng của quả biến đổi ổn định hơn do quá trình sinh trưởng của quả giảm, quả chuyển sang giai đoạn chuyển hóa các sản phẩm trao đổi chất là chính. Khi quả được 46 và 50 ngày tuổi chiều dài quả vẫn tăng lên nhưng không đáng kể, lúc này các giá trị không thể hiện sự khác nhau có ý nghĩa thống kê. Như vậy, trong quá trình sinh trưởng, phát triển của quả cà chua, sự tăng trưởng về chiều dài và đường kính có liên quan hữu cơ với nhau. Sự liên quan đó được điều khiển bởi các quá trình trao đổi chất cộng với sự điều hòa, chi phối của phức hệ các hoocmon nội sinh trong tế bào (Quinet et al., 2019).



Hình 1. Sự biến đổi về chiều dài và đường kính của quả cà chua trồng tại Thanh Hóa

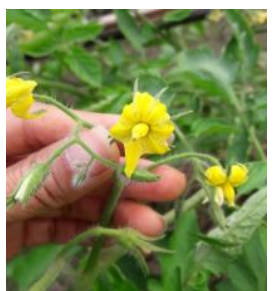

Thời điểm ra hoa



37 ngày

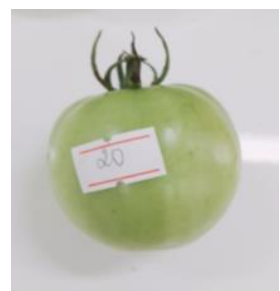

20 ngày



42 ngày

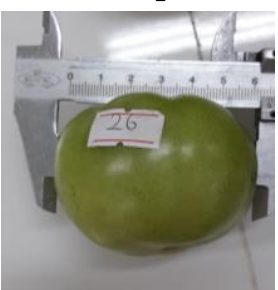

26 ngày



32 ngày



46 ngày



50 ngày

Hình 2. Sự sinh trưởng của quả cà chua trồng tại Thanh Hóa 


\subsection{Sự biến đổi hệ sắc tố theo tuổi phát triển của quả cà chua trồng tại Thanh Hóa}

Sự biến đổi trong hệ sắc tố vỏ quả là chỉ tiêu quan trọng cho phép xác định được những biến đổi màu sắc bên ngoài vỏ quả, từ đó làm căn cứ để xác định thời điểm thu hái quả thích hợp. Kết quả nghiên cứu sự biến đổi hệ sắc tố trong vỏ quả cà được thể hiện ở Hình 3. Ở những tuần tuối đầu tiên, hàm lượng diệp lục trong vỏ quả cà chua chiếm tỉ lệ cao: hàm lượng diệp lục a là $0,27 \mathrm{mg} / \mathrm{g}$ vỏ tươi, diệp lục $\mathrm{b}$ là $0,46 \mathrm{mg} / \mathrm{g}$ vỏ tươi vào thời điểm quả 7 ngày tuổi. Hàm lượng diệp lục trong vỏ quả cà chua đạt giá trị cao nhất vào thời điểm 26 ngày tuổi (diệp lục a là $0,35 \mathrm{mg} / \mathrm{g}$ vỏ tươi, diệp lục b là $0,64 \mathrm{mg} / \mathrm{g}$ vỏ tươi) thể hiện sự sai khác có ý nghĩa so với các thời điểm trước. Sau 26 ngày tuổi, hàm lượng diệp lục giảm dần và giảm nhanh ở thời điểm 46 và 50 ngày tuổi, điều này là do quả bắt đầu chuyển sang giai đoạn chín, sắc tổ diệp lục bị phân hủy và sắc tố carotenoid được tổng hợp.

Hàm lượng carotenoid trong vỏ quả cà chua tăng dần theo tuổi phát triển của quả. Trong những tuần đầu tiên của quả, hàm lượng carotenoid có giá trị thấp đạt $0,01 \mathrm{mg} / \mathrm{g}$ vỏ quả tươi ở 7 ngày tuổi. Thời kì quả từ 7 đến 26 ngày tuổi hàm lượng carotenoid tăng chậm, sau đó tăng nhanh theo sự chín của quả và khi quả 50 ngày tuổi thì hàm lượng carotenoid đạt $0,48 \mathrm{mg} / \mathrm{g}$ vỏ quả tươi và có sự khác biệt có ý nghĩa thống kê.

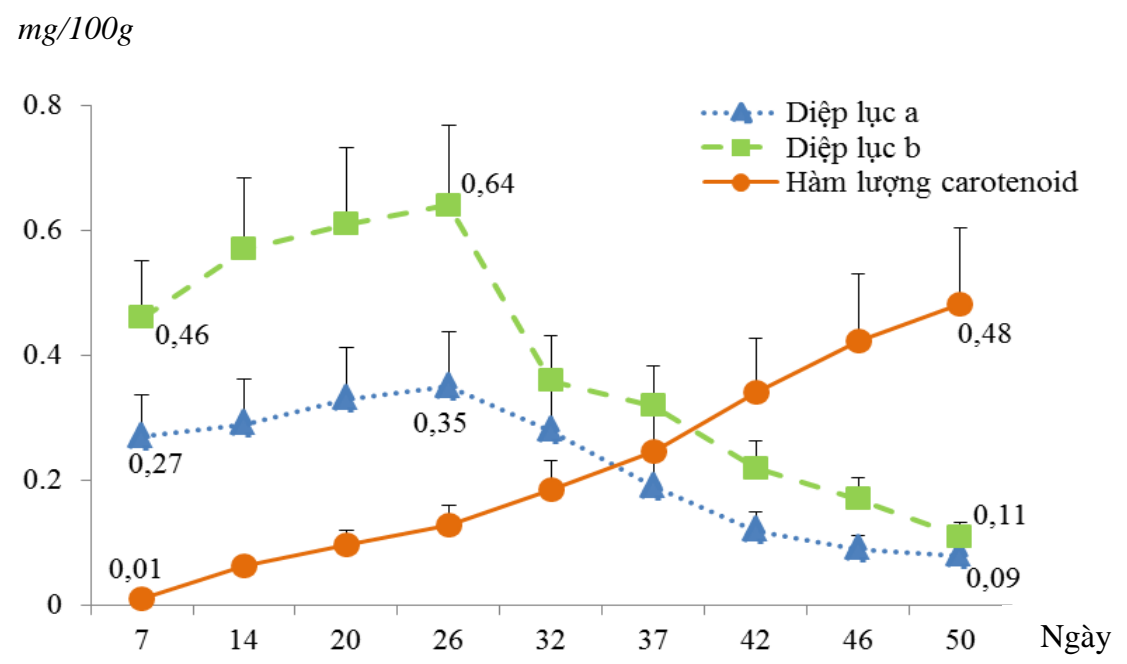

Hình 3. Sự biến đổi của hệ sắc tố vỏ quả cà chua trồng tại Thanh Hóa

Như vậy có thể thấy sự giảm hàm lượng diệp lục cùng với sự gia tăng lượng carotenoid theo tuổi phát triển của quả là phù hợp với quá trình quả cà chua phát triển và phản ánh đúng màu sắc quả khi chín. Kết quả này phù hợp với nghiên cứu của Wang et al. (2005) đó là sự thay đổi màu sắc trong quá trình chín của quả có liên quan đến sự suy thoái chất diệp lục.

\subsection{Sự biến đổi hàm lượng đường khử và tinh bột của quả cà chua trồng tại Thanh Hóa}

Đường khử là thành phần chính tạo nên độ ngọt của quả, hàm lượng và thành phần của nó thay đồi tùy vào từng giai đoạn phát triển của quả, trong khi đó tinh bột là thành phần dự trữ chủ yếu của nhiều loại quả. Nghiên cứu sự thay đổi hàm lượng đường khử và tinh bột theo tuổi của quả cho phép đánh giá một phần chất lượng của quả khi chín. Hình 4 cho thấy hàm lượng đường khử ở thời kì đầu trong quả cà chua ( 7 ngày) tương đối thấp đạt $0,85 \%$ khối lượng thịt quả tươi. Từ 7 đến 26 ngày tuổi, hàm lượng đường khử tăng chậm, sau giai đoạn này thịt quả tăng nhanh, các tế bào tiếp tục tăng sinh trưởng dãn, do vậy tăng sự tổng hợp năng lượng và các thành phần cấu thành nên tế bào (Heller et al., 1995). Thời kì quả từ 26 đến 46 ngày tuổi, hàm lượng đường khử tăng nhanh và đạt $3,47 \%$ khi quả 46 ngày tuổi, lúc này một lượng acid hữu cơ và tinh bột chuyển hóa thành đường, giá trị tại thời điểm này thể hiện sự sai khác ở mức ý nghĩa $\mathrm{P}<0,05$. Kết quả nghiên cứu này phù hợp với nghiên cứu về lượng đường tổng số tăng nhanh trong giai đoạn phát triển sau của quả (Patel et al., 2011). Ở thời điểm 50 ngày tuổi hàm lượng đường khử giảm xuống còn 3,29\% khối lượng thịt quả tươi. 




Hình 4. Sự biến đổi hàm lượng đường khử và tinh bột của quả cà chua trồng tại Thanh Hóa

Khi quả mới hình thành hàm lượng tinh bột thấp chỉ đạt $1,06 \%$ khối lượng thịt quả tươi ( 7 ngày tuổi), sau đó, sản phẩm của quang hợp từ lá và vỏ quả chuyển vào quả cung cấp nguyên liệu cho việc tổng hợp tinh bột nên hàm lượng tinh bột trong quả tăng dần (Nguyễn Như Khanh \& Lê Văn Trọng, 2012). Hàm lượng tinh bột cao nhất đạt $1,51 \%$ lúc quả 26 ngày tuổi và có sự sai khác thống kê ở mức ý nghĩa $\mathrm{P}<0,05$, sau 26 ngày hàm lượng tinh bột trong quả giảm dần do sự trao đổi chất trong quả diễn ra mạnh mẽ, dưới tác dụng của enzyme $\alpha$ - amylazse, tinh bột phân giải thành đường làm nguyên liệu trực tiếp cho quá trình hô hấp, trong giai đoạn này, hoạt độ của enzyme $\alpha$ - amylase cũng tăng lên.

\subsection{Sự biến đổi hàm lượng acid hữu cơ tổng số, hàm lượng vitamin $C$ của quả cà chua trồng tại Thanh Hóa}

Trong tế bào thực vật có thể gặp acid hữu cơ ở dạng tự do, dạng muối amon hoặc các este. Khi ở dạng este nó quy định chất lượng và mùi thơm của nhiều loại quả. Hàm lượng acid hữu cơ trong quả thay đổi tùy theo từng loài, giống và theo từng giai đoạn phát triển. Vitamin $\mathrm{C}$ là một acid hữu cơ tan trong nước được tổng hợp trong cơ thể thực vật và là thành phần dinh dưỡng chủ yếu của con người. Kết quả nghiên cứu sự biến đổi hàm lượng acid hữu cơ tổng số và hàm lượng vitamin $\mathrm{C}$ được thể hiện qua Hình 5 và Hình 6 .

Ở giai đoạn đầu khi quả mới hình thành đã tích luỹ lượng acid hữu cơ tổng số lớn đạt 40,12 meq/100g thịt quả tươi (meq: mili đương lượng). Thời kì quả từ 7 đến 26 ngày tuổi, hàm lượng acid hữu cơ tổng số tăng dần và đạt giá trị cao nhất là $48,13 \mathrm{meq} / 100 \mathrm{~g}$ thịt quả tươi ở 26 ngày tuổi, kết quả này có sự sai khác thông kê ở mức ý nghĩa $\mathrm{P}<0,05$. Sở dĩ có điều này là do ở trong quả, các quá trình trao đổi protein, trao đổi hydratcacbon, lipid diễn ra mạnh mẽ tạo ra nhiều sản phẩm trung gian như các aminoacid, ketoacid,... làm hàm lượng acid hữu cơ tăng lên (Gierson \& Kader,1986). Từ 26 đến 50 ngày tuổi, hàm lượng acid hữu cơ giảm do acid hữu cơ được sử dụng trong quá trình hô hấp tạo năng lượng cung cấp cho các quá trình tổng hợp tinh bột. Mặt khác, năng lượng lại tiếp tục cần cho sự sinh tổng hợp các chất đặc trưng cho thời kì chín của quả như các enzyme thủy phân tạo vị ngọt cho quả dẫn tới sự giảm dần của lượng acid tồng số (Prasanna et al., 2007).

Hàm lượng vitamin $\mathrm{C}$ từ ngày thứ 7 đến ngày 32 tăng nhanh, đây là thời kỳ thịt quả phát triển mạnh và có sự tích lũy vitamin $C$ cùng với các chất dinh dưỡng khác trong quả. Sau 32 ngày hàm lượng vitamin $\mathrm{C}$ vẫn tiếp tục tăng nhưng với tốc độ chậm hơn, đến ngày 46 đạt giá trị cao nhất là 33,68 $\mathrm{mg} / 100 \mathrm{~g}$ thịt quả tươi. Sau đó hàm lượng vitamin $\mathrm{C}$ giảm dần, đến 50 ngày tuổi hàm lượng vitamin $\mathrm{C}$ đạt $31,13 \mathrm{mg} / 100 \mathrm{~g}$ thịt quả tươi. Sự giảm hàm lượng vitamin $C$ có liên quan đến hoạt động của một số nhóm enzyme tham gia vào quá trình phân hủy ascorbic acid nhu ascorbate oxidase, phenolase, cytochrome oxidase, ascorbate peroxidase. Kết quả này phù hợp với nghiên cứu của Evellyn et al. (2012) đó là hoạt động của enzyme ascorbate peroxidase trong thịt quả tăng liên tục trong quá trình chín của quả. 


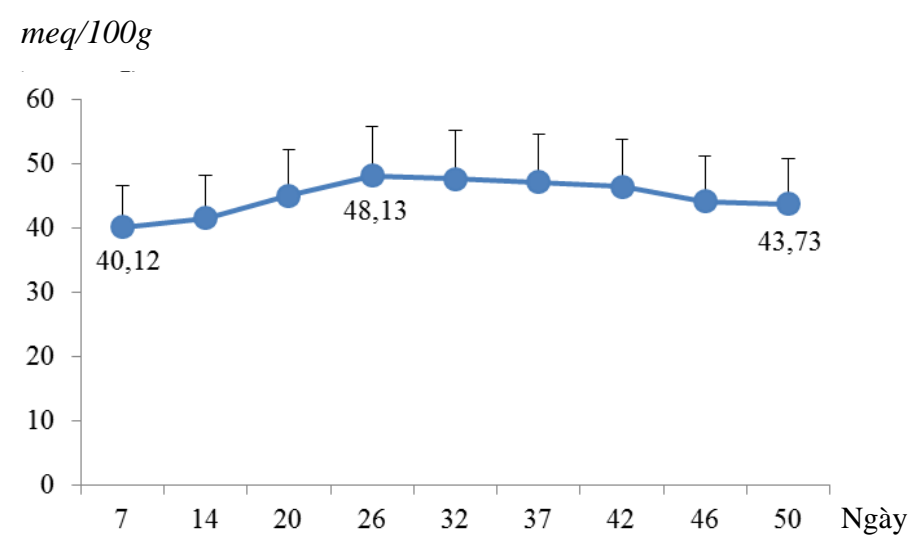

Hình 5. Sự biến đổi hàm lượng acid hữu cơ tổng số của quả cà chua trồng tại Thanh Hóa



\section{Hình 6. Sự biến đổi hàm lượng vitamin $\mathrm{C}$ của quả cà chua trồng tại Thanh Hóa}

\subsection{Sự biến đổi hoạt độ enzym $\alpha$ - amylase, catalase, peroxydase của quả cà chua trồng tại Thanh Hóa}

Hình 7 cho thấy khi quả mới hình thành ở thời điểm 7 ngày tuổi, hoạt độ $\alpha$ - amylase thấp (đạt 0,02 $\mathrm{UI} / \mathrm{g} / \mathrm{phút}$ ) và tăng chậm trong khoảng thời gian từ 7 đến 14 ngày tuổi. Từ 14 ngày tuổi trở đi, hoạt độ enzyme $\alpha$ - amylase trong quả tăng nhanh và đạt cực đại ở 46 ngày tuổi là $0,08 \mathrm{UI} / \mathrm{g} / \mathrm{phút}$, giá trị này có sự khác biệt qua phân tích thống kê, lúc này quả bước vào giai đoạn chín nên có sự phân giải mạnh mẽ tinh bột dưới tác dụng của enzyme $\alpha$ - amylase tạo đường làm nguyên liệu cung cấp cho hô hấp bùng phát và tạo vị ngọt cho quả, vì vậy giai đoạn này hàm lượng đường khử tăng lên và có sự giảm lượng tinh bột trong quả. Sau 46 ngày, hoạt động enzym $\alpha$ - amylase giảm dần. Kết quả này phù hợp với công bố của Luiz et al. (2001) đó là hoạt động của amylase trong quả tăng lên khi quả phát triển và giảm dần khi quả chuyển sang giai đoạn chín.

Từ khi quả mới hình thành hoạt độ catalase đã rất cao đạt $3,02 \mu \mathrm{M} \mathrm{H}_{2} \mathrm{O}_{2} / \mathrm{g} /$ phút ở thời điểm 7 ngày tuổi (Hình 8). Hoạt độ catalase tăng dần từ 7 đến 37 ngày tuổi, đạt cực đại tại 37 ngày tuổi với giá trị $10,81 \mu \mathrm{M} \mathrm{H}_{2} \mathrm{O}_{2} / \mathrm{g} /$ phút và khác biệt qua phân tích thống kê ở mức ý nghĩa $\mathrm{P}<0,05$. Trong giai đoạn này, trao đổi chất diễn ra mạnh mẽ, quả tăng nhanh về khối lượng, các phản ứng oxi hóa diễn ra mạnh mẽ, $\mathrm{H}_{2} \mathrm{O}_{2}$ tạo ra nhiều. Hoạt độ catalase cao, tăng cường phân giải $\mathrm{H}_{2} \mathrm{O}_{2}$, giải độc cho tế bào. Giai đoạn quả từ 37 đển 50 ngày tuổi hoạt độ catalase giảm, quả thiên về tích lũy chất đường, tinh bột, nước, các phản ứng oxi hóa chậm lại, $\mathrm{H}_{2} \mathrm{O}_{2}$ tạo ra ít hơn. 


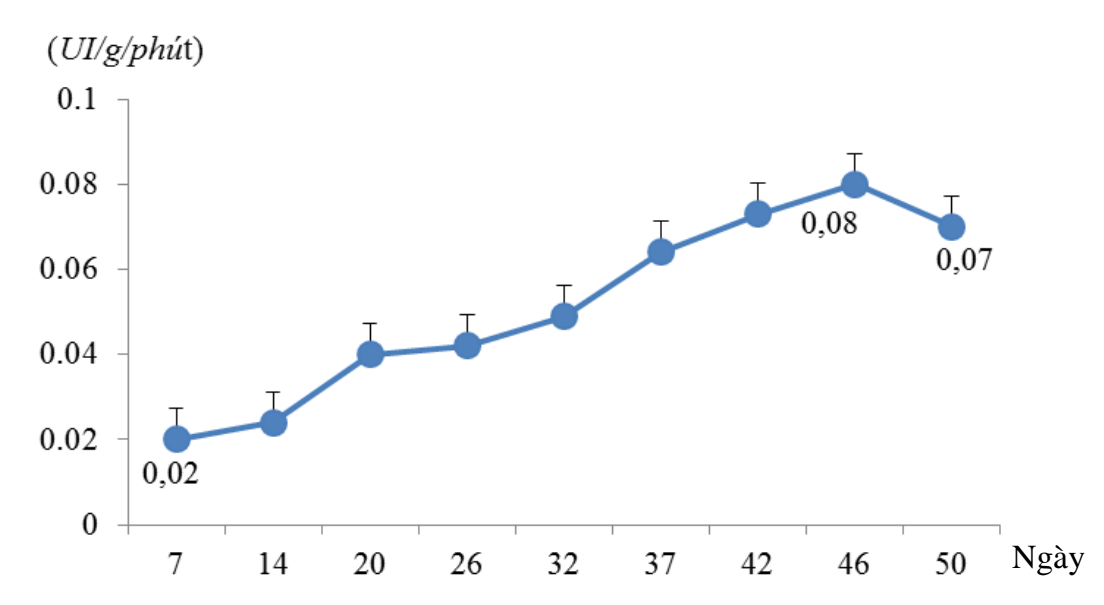

Hình 7. Sự biến đổi hoạt độ enzyme $\alpha$ - amylase của quả cà chua trồng tại Thanh Hóa

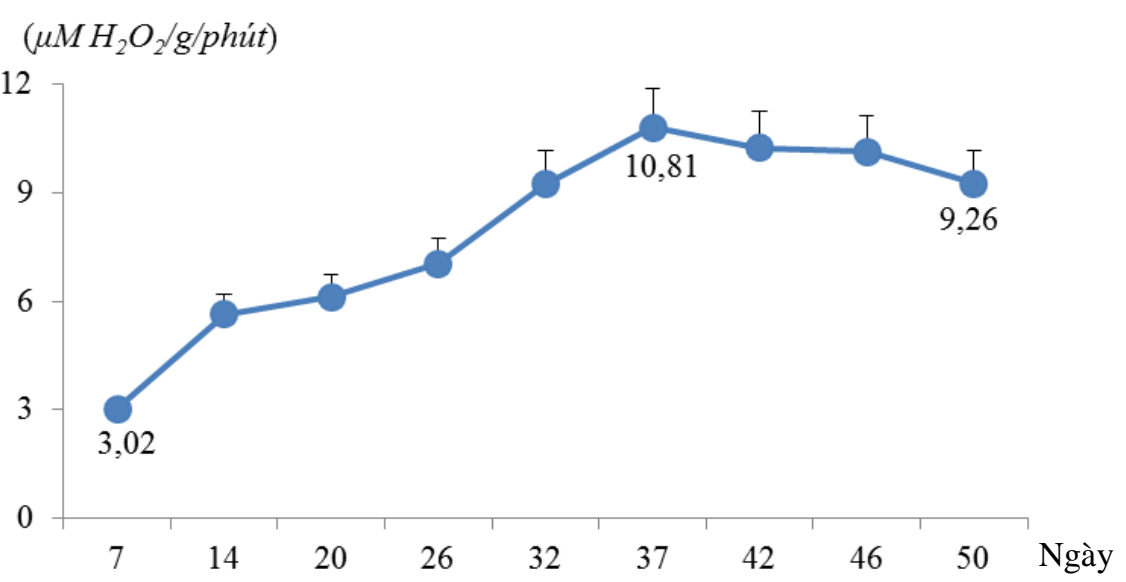

Hình 8. Sự biến đổi hoạt độ enzyme catalase của quả cà chua trồng tại Thanh Hóa

\section{(UI/g/giây)}

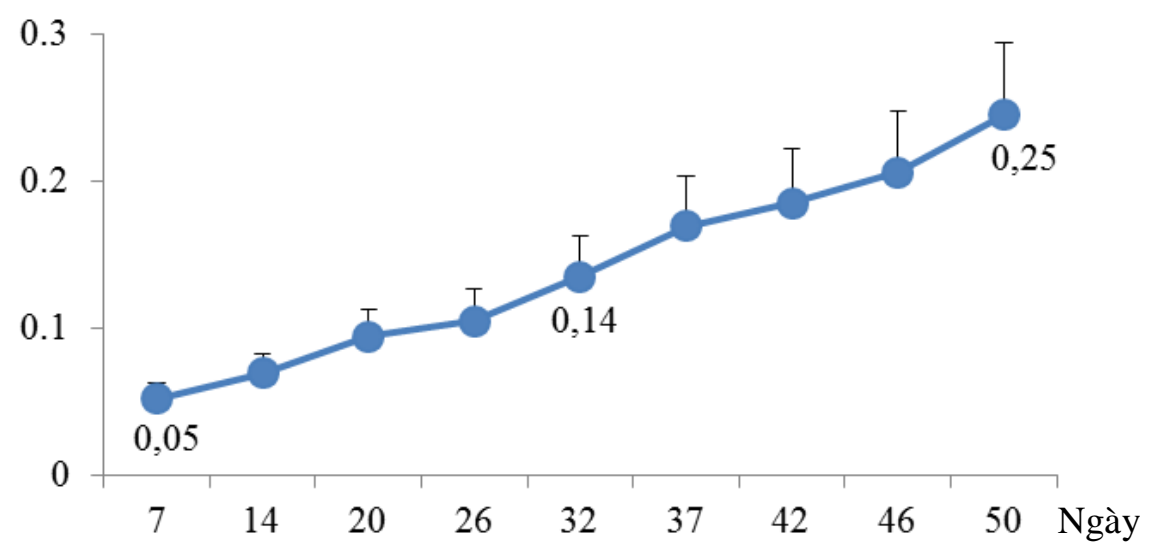

Hình 9. Sự biến đổi hoạt độ enzyme peroxydase của quả cà chua trồng tại Thanh Hóa 
Giai đoạn quả từ 7 đến 32 ngày tuổi, hoạt độ enzyme peroxydase thấp và tăng chậm (từ 0,05 $\mathrm{UI} / \mathrm{g} /$ giây đến $0,14 \mathrm{UI} / \mathrm{g} /$ giây) vì lúc này quá trình oxi hóa các chất diễn ra mạnh mẽ thải ra lượng $\mathrm{H}_{2} \mathrm{O}_{2}$ lớn, sự phân giải $\mathrm{H}_{2} \mathrm{O}_{2}$ thuộc về catalase. Từ 32 đến 50 ngày tuổi hoạt độ của enzyme peroxydase tăng nhanh (từ $0,14 \mathrm{UI} / \mathrm{g} /$ giây đến $0,25 \mathrm{UI} / \mathrm{g} /$ giây) và có sự khác biệt qua phân tích thống kê, điều này là do sự oxi hóa các chất giảm, nồng độ $\mathrm{H}_{2} \mathrm{O}_{2}$ trong quả thấp hơn, quá trình phân giải $\mathrm{H}_{2} \mathrm{O}_{2}$ do peroxydase đảm nhận, lúc này enzyme peroxydase xúc tác cho phản ứng phân giải tanin để quả bước vào giai đoạn chín nên tạo ra nhiều các hợp chất vòng, ngoài ra enzyme này còn xúc tác cho các phản ứng chuyển hóa các hợp chất vòng, các indol, các amin vòng. Mặt khác, nó cũng liên quan đến việc tạo etylen hormon kích thích quá trình chín của quả (Ku et al., 1970).

\section{KẾT LUẬN}

Quả cà chua giống NHP11 trồng trong vụ Xuân 2019 tại Thanh Hóa vào thời điểm 46 ngày đạt kích thước gần như tối đa cả về chiều dài và đường kính. Màu sắc quả lúc này chuyển sang màu đỏ nhạt do sự giảm hàm lượng diệp lục và tăng hàm lượng carotenoid. Ở thời điểm này quả có giá trị cực đại về hàm lượng đường khử và vitamin $\mathrm{C}$, trong khi đó các thành phần khác như tinh bột và acid hữu cơ tổng số biến đổi theo sự sinh trưởng và sự chín của quả. Hoạt độ của enzyme $\alpha$ - amylase biến động phù hợp với sự biến động của tinh bột và đường khử theo tuồi phát triển. Hoạt độ cactalase tăng dần và đạt cực đại khi quả 46 ngày tuổi rồi giảm dần. Hoạt độ peroxydase tăng liên tục từ khi quả hình thành đến khi chín. Sau 46 ngày tuổi, một số thành phần chính của quả như hàm lượng đường khử và vitamin $\mathrm{C}$ giảm xuống. Do vậy, đây là thời điểm thu hái thích hợp nhất, nếu thu hái sớm hơn hay muộn hơn sẽ ảnh hưởng đến chất lượng của quả.

\section{TÀI LIÊUU THAM KHẢO}

Abdul, H.M., Bello, I. A., \& Olajire, A. A. (2009). Comparison of biochemical and physiological properties of nigerian tomato fruits ripened under different conditions. African Journal of Food, Agriculture, Nutrition and Development, 9(9), 1859-1877.

Cao Kỳ Sơn, Phạm Ngọc Tuấn \& Lê Minh Lương. (2008). Nghiên cứu lựa chọn giá thể cứng thích hợp trồng dưa chuột, cà chua thương phẩm trong nhà plastic theo hướng sản xuất nông nghiệp công nghệ cao. Tạp chí Khoa hoc đẩt, 31, 25-36.

Dương Bá Toàn. (2017). Kỹ thuật trồng cà chua, dua chuôt . Nhà xuất bản Phương Đông. Cà Mau. 111 trang.
Erba, D., Casiraghi, M. C., Ribas-Agusti, A., Cáceres, R., Marfà, O. \& Castellari, M. (2013). Nutritional value of tomatoes (Solanum lycopersicum L.) grown in greenhouse by different agronomic techniques. Journal of Food Composition and Analysis, 31(2), 245-251.

Ermakov, A. I., Arasimovich, V. E., SmirnovaIkonnikova, M. I., Yarosh, N. P. \& Lukovnikova, G. A. (1972). The methods of biochemical study of the plants. Leningrad: Kolos.

Evellyn, C. O. R., Paula, F. M., Ricardo, A. A., Angelo, P.J. \& Ilana, U. B. (2012). Oxidative processes during "Golden" papaya fruit ripening. Braz. J. Plant Physiol, 24(2), 85-94.

Gierson, D. \& Kader, A. A. (1986). Fruit ripening and quality. In: Atherton, J. G. and Rudich, J. (Eds.). The Tomato Crop. Chapman and Hall (pp. 241-280). London/New York.

Hartz, T., Miyao, G., Mickler, J. et al. (2008). Processing tomato production in California UC Vegetable Research and Information Center, 7228, 1-5.

Heller, R., Esnault, R. \& Lance, C. (1995). Physiologie végétale, Développement, $15 \mathrm{e}$ e'dition. Masson II. Paris Milan Bacelone. French.

Ku, H. S., Yang, S. F. \& Pratt, H. K. (1970). Ethylene production and peroxidase activity during tomato fruit ripening. Plant and cell physiology, 11(2), 241-246.

Luiz, C. O. L., Adimilson, B. C. \& Maria, I. F. C. (2001). Changes in amylase activity starch and sugars contents in mango fruits pulp cv. Tommy atkins with spongy tissue, Braz. Arch. Biol. Technol, 44(1), 59-62.

Nguyễn Như Khanh \& Lê Văn Trọng. (2012). Một số chuyển hóa sinh lý, hóa sinh theo tuổi phát triển của quả cam (Citrus sinensis Linn.Osbeck) giống cam Sông con trồng tại Yên Định, Thanh Hóa, Tap chi Khoa hoc Truòng Đại hoc Su pham Hà Nội, 57(3), 89-98.

Nguyễn Văn Mã, La Việt Hồng \& Ong Xuân Phong. (2013). Phuong pháp nghiên cúu sinh lý học thục vật. Nhà xuất bản Đại học Quốc gia Hà Nội. Hà Nội.

Nguyễn Văn Mùi. (2001). Thưc hành hóa sinh học. Nhà xuất bản Đại học Quốc gia Hà Nội. Hà Nội.

Nguyễn Văn Thao, Nguyễn Thu Hà \& Đỗ Nguyên Hải. (2016). Ảnh hưởng của các mức đạm, lân, kali đến cây cà chua trồng trên giá thể hữu cơ. Tạp chi Khoa học Nông nghiẹp Việt Nam, 14(8), 1307-1318.

Patel, P. R., Gol, N. B. \& Rao, T. V. R. (2011). Physiochemical changes in sunberry (Physalis minima L.) fruit during growth and ripening. Fruits, 66(1), 37-46. 
Phạm Thị Trân Châu, Nguyễn Thị Hiền \& Phùng Gia Tường. (1996). Thưc hành hóa sinh hoc. Nhà xuất bản Giáo dục. Hà Nội.

Poonam, B., Nanjappa, A., Tissa S. \& David, M. (2004). Tissue culture studies of tomato (Lycopersicon esculentum) Plant Cell. Tissue and Organ Culture, 78(1),1-21.

Prasanna, V., Prabha, T. N. \& Tharanathan, R. N. (2007). Fruit ripening phenomena-an overview. Critical Reviews in Food Science and Nutrition, 47(1), 1-19.
Quinet, M., Angosto, T., Yuste-Lisbona, F. J., Blanchard-Gros, R., Bigot, S., Martinez, J. P., \& Lutts, S. (2019). Tomato fruit development and metabolism. Frontiers in plant science, 10, 1554.

Tạ Thu Cúc. (2009). Kỹ thuật trồng cà chua. Nhà xuất bản Nông nghiệp. Hà Nội.

Wang, H. C., Huang, X. M., Hu, G. B., Yang, Z. \& Huang, H. B. (2005). A comparative study of chlorophyll loss and its related mechanism during fruit maturation in the pericarp of fastand slow-degreening litchi pericarp. Science Horticultural, 106, 247-257. 